\title{
KOMPOS ORGANIK DENGAN PEROMBAK AGRI SIMBA DAN PENGARUHNYA TERHADAP PERAKARAN KACANG TANAH (Arachis hipogaea L.)
}

\author{
Saiful Ridlo \\ Biologi, FMIPA, UNNES \\ Gd.D6 It.1 Kampus Sekaran Gunungpati \\ Semarang 50229
}

\begin{abstract}
The dried rice stalks and banana stem are waste product after their harvesting but have potential as organic compost. Organic compost fertilizer treatment has a purpose to give nutrient for growth media until the root had enough and grow well. In this study, a peanuts root of two cultivars, kelinci and gajah, were grew in soil growth media which enrich an organic compost fertilizer, i.e. dried rice stalks, banana stem and mix of both composting with Agri Simba as starter, would be compared with control to look the kinds of growth media, cultivars and their interaction affect on rooting. The method used in this study was on experiment with on experimental design called completely randomized design. Each unit of the treatment tested four times. Many parameters would be studied in this case: length of the primary root, sum of live root apical, sum of nodules. They analyzed by two ways ANOVA test. Anatomical structure was analyzed by descriptive method. Harvesting of the cell have done $8^{\text {th }}$ and $20^{\text {th }}$ day after planting. The result of this study showed that organic composts have variation content of the $N, P$, and $K$ on three kind of compost, certainly. The growth media treatment affected significantly $(p<0.05)$ in peanut rooting at less on root length and on sum of live root apical in early growth phase and sum of nodules in secondary growth. The cultivars treatment affected significantly $(p<0,05)$ on peanut rooting at less on sum of live root apical but not $(p>0.05)$ on root length and sum of nodules. Their interaction treatment not affected $(p>0.05)$ on rooting parameter observed. The treatments may affect on anatomical structure.
\end{abstract}

Key word: rooting, Agri Simba, Arachis hypogaea, organic compost fertilizer

\section{PENGANTAR}

Pertanian organik pada prinsipnya adalah memberi makanan tanah sehingga tanah dapat memberi makan tanaman. Pada budi daya pertanian organik, unsur hara secepatnya dipindahkan dari limbah organik menjadi biomassa tanah yang selanjutnya akan mengalami mineralisasi (Herlina dkk., 2001) yang menghasilkan zatzat organik sederhana. Zat-zat tersebut berguna bagi mikroba saprofitik dan bagi pembentukan perakaran tanaman (Rao, 1994). Selain menambah unsur hara makro dan mikro di dalam tanah, pupuk organik terbukti sangat baik dalam memperbaiki struktur tanah (Lingga dan Marsono, 2000).

Untuk mempercepat mineralisasi/dekomposisi dari limbah organik secara fermentatif untuk menghasilkan kompos dapat digunakan Agri Simba. Agri Simba merupakan kelompok mikroba zimogenik yang terdiri atas Bacillus, Ragi, Lactobacillus, Azotobacter dan Acetobacter yang bekerja sinergis. Mikroba-mikroba tersebut diseleksi dan diisolasi dari tanah perkebunan dan dikemas dalam bentuk suspensi. Mikroba dalam Agri Simba mampu mengaktifkan proses pengayaan unsur hara untuk pertanian organik sehingga dapat mempercepat proses penyediaan unsur hara tanaman, menyuburkan tanah, memperbaiki tekstur tanah, mencegah penyakit akar dan mengefektifkan penyerapan hara (PPAU-IH ITB, 1998).

Kompos bisa dibuat dari limbah pertanian seperti jerami, daun tebu, batang pisang, serasah, dan sebagainya. Pemberian Agri Simba dapat mempercepat pembuatan kompos sekitar 7-10 hari lebih cepat (PPAU-IH ITB, 1998). Kadar hara kompos sangat ditentukan oleh bahan yang dikomposkan, cara pengomposan, dan cara penyimpanannya. Kadar hara kompos tidak pernah tinggi, oleh karena itu sering ditambahkan zat kimia unsur N, P, dan K sehingga kadar NPK-nya lebih tinggi (Lingga dan Marsono, 2000).

Hara akan masuk ke dalam tubuh tanaman pertamatama melalui akar, ironisnya akar merupakan organ tanaman yang paling sedikit diteliti dan dibicarakan. Semakin baik pertumbuhan akar tentu akan berpengaruh terhadap pertumbuhan organ lain dari tanaman mengingat fungsi akar sebagai alat untuk menyerap hara (Peterson, 1992). Seperti tanaman lain, pada kacang tanah penyerapan hara setiap kultivar juga berlainan mengingat potensi hasil atau biomassa, umur dan tingkat efisiensi penggunaan hara. Tanah yang mengandung bahan organik dalam persentase yang terlalu tinggi justru tidak diperlukan oleh tanaman 
kacang tanah karena akan menurunkan produksi (Pukan, 1999 dan Herlina dkk., 2001). Salah satu tujuan pemberian pupuk adalah untuk merangsang pertumbuhan awal dan perkembangan akar tanaman (Lingga dan Marsono, 2000) termasuk dalam pertanian organik. Sebenarnya tanaman kacang tanah dapat memenuhi sendiri unsur $\mathrm{N}$ yang dibutuhkan melalui simbiosis dengan Rhizobium, tetapi pemberian pupuk $\mathrm{N}$ dibutuhkan sebagai starter selama kacang tanah belum mampu memenuhi kebutuhan $\mathrm{N}$ dengan bintil akar. Irianti (1999) menyatakan pemupukan nitrogen dalam jumlah kecil pada awal pertumbuhan dapat merangsang pertumbuhan dan pembentukan bintil akar.

Dalam bintil akar pada akar kacang tanah tertambat nitrogen, sehingga apabila dieksploitasi secara maksimal akan memberikan keuntungan ganda (Sinnot, 1979). Menurut Pukan (1999), jumlah nitrogen yang tertambat oleh asosiasi legum dan Rhizobium sangat bervariasi tergantung legumnya, kultivarnya, spesies, dan galur bakterinya serta kondisi pertumbuhannya terutama $\mathrm{pH}$ dan kandungan nitrogen tanah.

Tidak semua sel akar mempunyai kemampuan merespons sama terhadap stimulus oleh infeksi bakteri. Faktor kimia yang berpengaruh terhadap nodulasi datang dari kotiledon, daun, initial akar lateral, dan dari bintil lain. Interaksi antara kedua simbion dari awal pembintilan sampai berkembangnya bintil secara utuh juga dikontrol oleh gen-gen dari kedua simbion (Peterson, 1992). Faktor eksternal dalam beberapa hal lebih banyak berpengaruh daripada faktor endogen. Faktor tersebut berupa mineral tanah, adanya ion kalsium dalam konsentrasi yang tinggi, $\mathrm{pH}$, dan efek inhibitori nitrat. Waktu yang direkomendasikan untuk mendeterminasi bintil adalah sebelum tanaman berbunga sebab kemudian bintil akan mengkerut dan warnanya kusam. Faktor eksternal akar berupa tanah dan hara yang ada di dalamnya juga dipengaruhi campur tangan manusia, antara lain lewat pemupukan organik dengan kompos (Pukan, 1999). Karena itu perlu diteliti akibat pemberian pupuk kompos organik dan macam kultivar kacang terhadap pertumbuhan akar dan implikasinya terhadap struktur anatominya.

\section{BAHAN DAN CARA KERJA}

\section{Bahan Penelitian}

Jerami padi dan batang pisang yang dicacah sebanyak @ 25 kg diperoleh dari petani dusun Belik, Kalisegara, Gunungpati-Semarang. Agri Simba (EM 4 produksi PT Rekayasa Sumber Hayati atas lisensi Kantor Manajemen HAKI / PAU Ilmu Hayati ITB) sebanyak satu liter diperoleh dari Laboratorium PAU Ilmu Hayati Institut Teknologi
Bandung. Tetes tebu sebanyak 0,5 liter dan pupuk NPK diperoleh dari Trubus, Ungaran-Semarang. Biji kacang tanah kultivar Kelinci dan kultivar Gajah yang mempunyai biji 2 tiap polongnya diperoleh dari Toko Pertanian Subur Yogyakarta.

\section{Cara Kerja}

Penelitian dilakukan di Laboratorium Jurusan Biologi FMIPA UNNES. Penelitian ini dilakukan secara eksperimental dengan desain acak lengkap pola faktorial ( $2 \times 4$ taraf perlakuan). Faktor 1 adalah jenis kompos bahan organik terdapat: A0 (tanpa kompos), A1 (kompos organik dari bahan jerami padi), A2 (kompos organik dari batang pisang) dan A3 (kompos organik dari campuran jerami dan batang pisang). Faktor 2 adalah kultivar kacang tanah terdiri atas B1 (kultivar Kelinci) dan B2 (kultivar Gajah). Setiap perlakuan diulang 4 kali dan setiap unit dipanen 2 kali sehingga seluruhnya terdapat $(4 \times 2 \times 4) \times 2=64$ unit percobaan. Masing-masing unit percobaan ditempatkan dalam polybag. Adapun cara kerjanya sebagai berikut.

Langkah pertama, dilakukan pembuatan kompos. Jenis kompos yang dibuat adalah kompos bahan jerami, batang pisang dan campuran jerami-batang pisang (1:1) yang dibuat dengan Agri Simba sebagai starter untuk mempercepat dekomposisi. Larutan Agri Simba diaktifkan dengan cara mencampurkan 0,1 liter Agri Simba dengan 5 liter air ditambah 0,05 liter tetes tebu ditambah lagi dengan 0,05 kg NPK. Larutan didiamkan selama sehari semalam, seperti disarankan oleh PPAU-IH ITB (1998). Larutan tersebut selanjutnya disebut starter cair. Bahan kompos berupa jerami dan batang pisang yang dicacah diambil @ 17 kg kemudian keduanya dicampurkan sehingga terdapat $17 \mathrm{~kg}$ jerami, $17 \mathrm{~kg}$ batang pisang dan $16 \mathrm{~kg}$ campuran jerami dan batang pisang yang telah dicacah. Larutan starter cair yang telah dibuat kemudian dibagi menjadi tiga bagian dan masing-masing disiramkan pada bahan kompos tersebut. Bahan diperam selama 14 hari dan selama pemeraman campuran diaduk-aduk 5 kali.

Kompos yang telah masak dianalisis di Laboratorium Pengujian Limbah dan Lingkungan dan Aneka Komoditi, BPPI Semarang. Kandungan N (nitrogen) dianalisis dengan uji makro Kjeidal, kandungan $\mathrm{P}$ (phosphor) dianalisis dengan spektrofotometri, dan kandungan K (kalium) dianalisis dengan AAS.

Langkah kedua, penyiapan media tanam. Media tanam berupa tanah kebun yang belum pernah ditanami kacangkacangan dimasukkan ke dalam polybag sebanyak 6 kg per polybag seperti dilakukan Suryati (2000), diberi pupuk kompos organik (yang telah disiapkan seperti di atas) masing-masing sebanyak $10 \mathrm{~g}$ dan ditanami benih kacang 
masing-masing 3 biji per polybag. Teknik pemilihan biji kacang sebagai sampel yang digunakan adalah random sampling. Perhitungan pemberian pupuk kompos organik sesuai kebutuhan tanaman kacang seperti ditulis oleh Rukmana (1998). Untuk kelompok kontrol hanya digunakan media tanam tanah kebun. Selanjutnya ditempatkan pada sel-sel penelitian sesuai dengan rancangan penelitian.

Langkah ketiga, dilakukan pemeliharaan tanaman dengan cara disiram air sumur pada pagi hari. Pada setiap 2 minggu sekali disiram dengan starter cair, dibuat dengan cara di atas, kecuali pada kelompok kontrol. Pada hari ke-5 setelah tanam dipilih tanaman yang memperlihatkan pertumbuhan baik dan 2 tanaman yang lain dimatikan dengan cara dipotong.

Langkah keempat, pemanenan pertama pada 8 hari setelah tanam di mana belum terbentuk bintil akar dilakukan dengan flotation method, seperti ditunjukkan oleh Bohm (1979). Parameter yang diamati adalah panjang akar primer dan jumlah ujung akar yang hidup. Pemanenan kedua dilakukan pada 20 hari setelah tanam di mana bintil telah terbentuk dan aktif untuk pertumbuhan vegetatif. Parameter yang diamati adalah jumlah bintil akar pada akar primer dan anatomi akar pada daerah bintil. Pengamatan anatomi dilakukan dengan cara pengirisan pada daerah $2 \mathrm{~cm}$ di bawah leher akar, di mana telah dijumpai bintil akar, dengan metode irisan tangan bebas dan diwarnai dengan safranin $1 \%$ dalam air.
Data tentang panjang dan jumlah yang diperoleh dianalisis dengan analisis varian dua arah pada taraf signifikansi 5\% $(\alpha=0,05)$. Sedangkan anatomi akar pada daerah bintil dianalisis secara diskriptif kualitatif.

\section{HASIL}

Hasil analisis unsur hara N, P, dan K pada kompos bahan organik jerami, batang pisang dan campuran jeramibatang pisang $1: 1$ selama 14 hari dengan Agri Simba sebagai perombaknya menunjukkan adanya variasi sebagaimana dapat dilihat pada Tabel 1.

Tabel 1. Analisis kadar $\mathrm{N}, \mathrm{P}$ dan $\mathrm{K}$ pada kompos bahan organik jerami, batang pisang, dan campuran jerami-batang pisang $1: 1$ untuk bokasi 14 hari

\begin{tabular}{ccccc}
\hline Unsur & \multicolumn{3}{c}{ Kadar unsur (\%) dalam } & Metode Uji \\
& \multicolumn{3}{c}{ Kompos } \\
& $\begin{array}{c}\text { Jerami } \\
\text { (A1) }\end{array}$ & $\begin{array}{c}\text { Bt. Pisang Campuran } \\
\text { (A2) }\end{array}$ & $\begin{array}{c}\text { A1+A2 } \\
\text { (A3) }\end{array}$ \\
\hline Nitrogen (N) & 0,71 & 0,10 & 0,42 & Makro Kjeidal \\
Phosphor (P) & 0,26 & 0,20 & 0,18 & $\begin{array}{c}\text { Spektrofoto- } \\
\text { metri }\end{array}$ \\
Kalium (K) & 0,22 & 0,23 & 0,15 & AAS \\
\hline
\end{tabular}

Keterangan: Berdasarkan hasil uji Laboratorium Pengujian Limbah dan Lingkungan dan Aneka Komoditi, BPPI Semarang

Tabel 2. Nilai rata-rata hasil pengukuran beberapa parameter pada akar kacang tanah

\begin{tabular}{|c|c|c|c|c|c|c|}
\hline \multirow{2}{*}{$\begin{array}{l}\text { Parameter } \\
\text { Panjang akar } \\
\text { primer (cm) }\end{array}$} & \multirow{2}{*}{$\begin{array}{c}\begin{array}{c}\text { Panen } \\
\text { (hari setelah } \\
\text { tanam) }\end{array} \\
8\end{array}$} & Perlakuan & \multirow{2}{*}{$\begin{array}{c}\text { A0 } \\
17,300\end{array}$} & \multirow{2}{*}{\begin{tabular}{|c|} 
A1 \\
33,850
\end{tabular}} & \multirow{2}{*}{$\begin{array}{c}\text { A2 } \\
29,775\end{array}$} & \multirow{2}{*}{$\begin{array}{c}\text { A3 } \\
31,325\end{array}$} \\
\hline & & B1 & & & & \\
\hline & & B2 & 24,350 & 31,175 & 22,800 & 28,475 \\
\hline & & $F_{\text {hit (A) }}: 7,250$ & : 1,256E-03) & & & \\
\hline & & $F_{\text {hit (B) }}: 0,525$ & $0,4756)$ & & & \\
\hline & & $\mathrm{F}_{\text {hit (AB) }}: 2,505$ & : 0,0833) & & & \\
\hline \multirow[t]{5}{*}{ Jumlah ujung akar hidup } & 8 & B1 & 85,750 & 86,250 & 121,250 & 123,000 \\
\hline & & B2 & 86,250 & 72,500 & 93,500 & 90,750 \\
\hline & & $F_{\text {hit (A) }}: 11,2$ & (p: 8,150E-05) & & & \\
\hline & & $F_{\text {hit (B) }}: 18,3$ & (p: 2,563E-04) & & & \\
\hline & & $\mathrm{F}_{\text {hit }(\mathrm{AB})}: 3,00$ & o: 0,0504) & & & \\
\hline \multirow[t]{5}{*}{ Jumlah bintil pada akar primer } & 20 & B1 & 16,000 & 36,250 & 35,750 & 27,750 \\
\hline & & B2 & 15,750 & 45,250 & 33,750 & 22,750 \\
\hline & & $\mathrm{F}_{\text {hit (A) }}: 17,5$ & (p: 3,056E-06) & & & \\
\hline & & $\mathrm{F}_{\text {hit (B) }}: 0,02 \varepsilon$ & ০: 0,8681) & & & \\
\hline & & $\mathrm{F}_{\text {hit (AB) }}: 1,34$ & $0,2849)$ & & & \\
\hline
\end{tabular}

Keterangan: $F_{\text {hit }(A),} F_{\text {hit }(B),} F_{\text {hit }(A B)}$ merupakan besarnya nilai $F$ hitung pada varian $A$, B dan interaksi $A$ dan $B ; p$ adalah nilai probabilitas; ${ }^{*}$ signifikan $(p<0,05)$; ns : non signifikan $(p>0,05)$ 
Hasil pengukuran beberapa parameter teramati dan hasil analisis varian dua arah pada masing-masing parameter dapat dilihat pada Tabel 2.

Pada tabel, menunjukkan bahwa pemberian kompos bahan organik jerami, batang pisang, dan campuran jeramibatang pisang berpengaruh terhadap perakaran kacang tanah paling tidak pada panjang akar $(\mathrm{p}<0,05)$ dan jumlah ujung akar yang hidup $(\mathrm{p}<0,05)$ pada awal pertumbuhan tanaman, dan jumlah bintil akar $(\mathrm{p}<0,05)$. Macam kultivar kacang berpengaruh secara signifikan terhadap jumlah ujung akar yang hidup $(\mathrm{p}<0,05)$ tetapi tidak pada parameter panjang akar ( $p>0,05)$, dan jumlah bintil akar ( $p>0,05)$. Pengaruh interaksi antara pemberian kompos bahan organik dan kultivar terhadap perakaran tidak berbeda nyata pada parameter-parameter yang diamati $(\mathrm{p}>0,05)$.

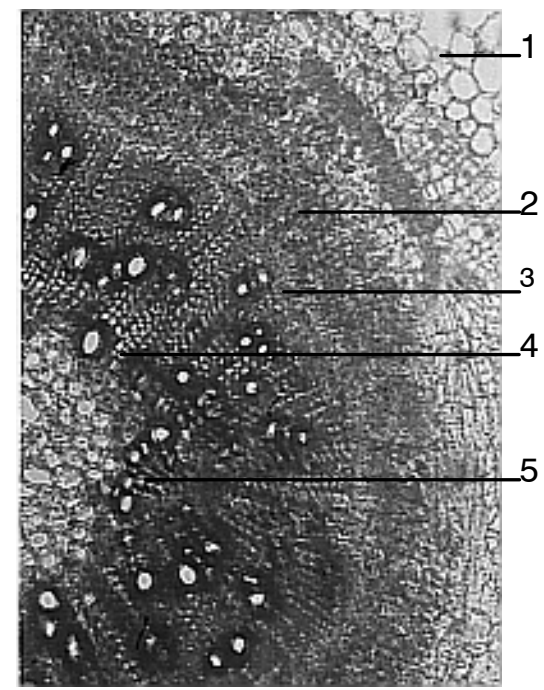

A0B1

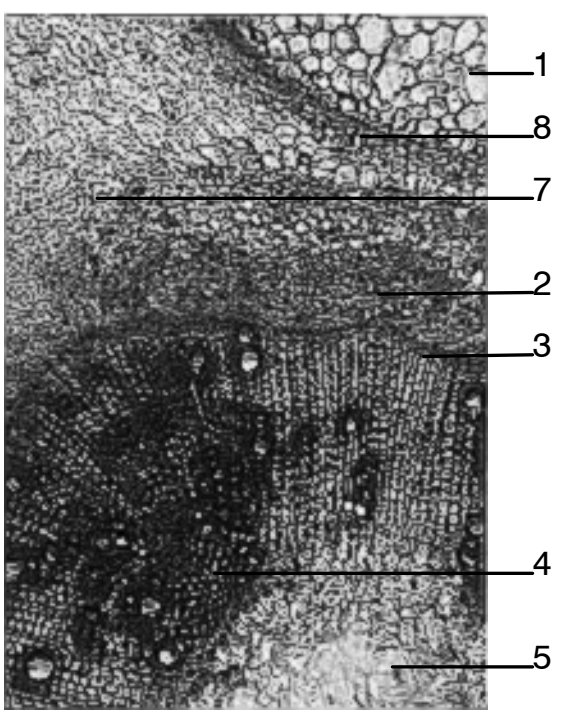

A1B1
Pengirisan yang dilakukan pada daerah bintil akar pada centimeter kedua di bawah leher akar pada panen 20 hari setelah tanam menunjukkan bahwa umumnya akar telah mengalami pertumbuhan sekunder. Korteks akar tampak lebih sempit karena pertumbuhan dari dalam dan robek karena pertumbuhan bintil yang mendesak keluar. Pola tetrarch protoxilem yang dijumpai pada fase pertumbuhan primer tampak menjadi tidak jelas kecuali pada akar kacang tanah yang ditumbuhkan pada media tanpa kompos. Jarijari xilem yang terbentuk pada kacang tanah yang ditumbuhkan pada media tanpa kompos lebih sempit dibandingkan dengan yang lain. Akar-akar yang ditumbuhkan pada media berkompos, metaxilemnya dijumpai meluas sampai ke arah kambium. Hasil pengamatan anatomi akar pada dapat dilihat pada Gambar 1.

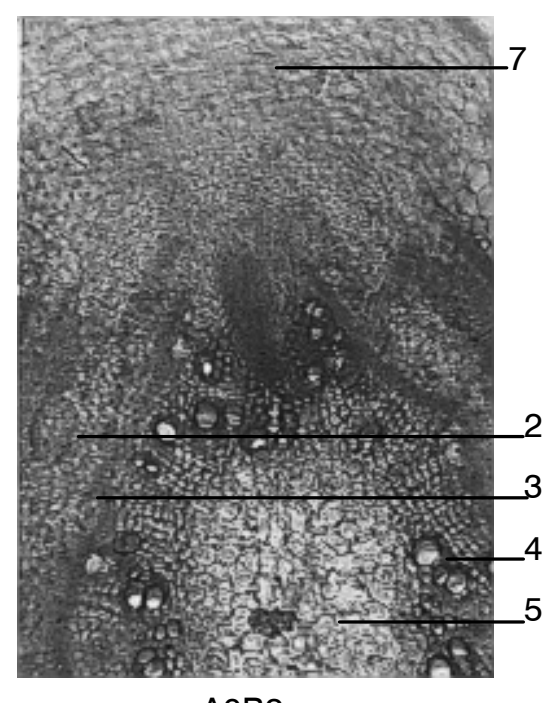

A0B2

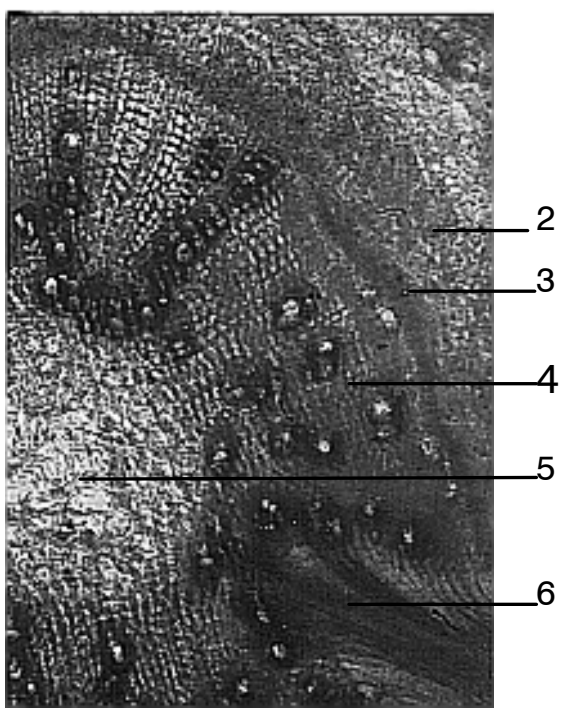

A1B2 


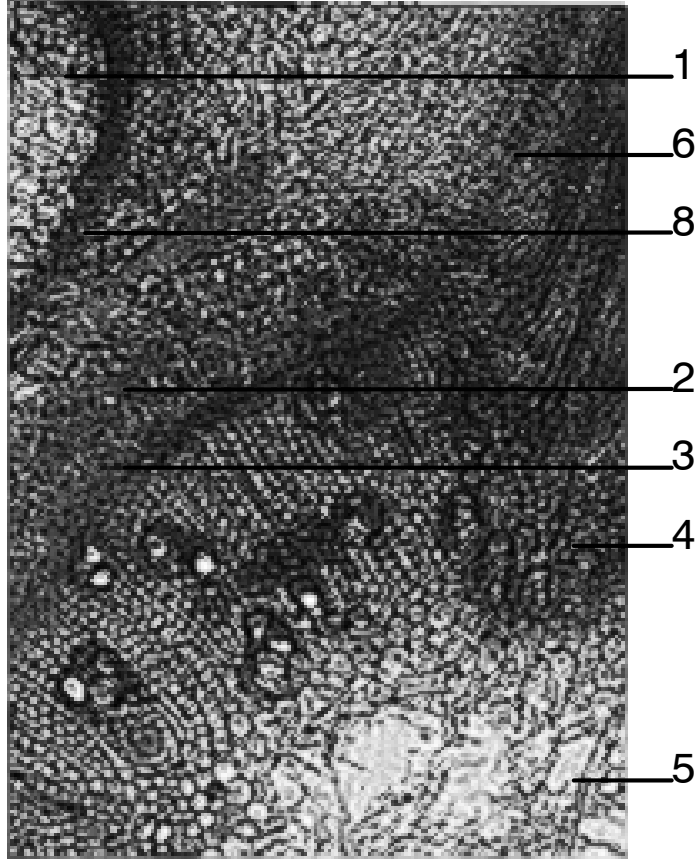

A3B1

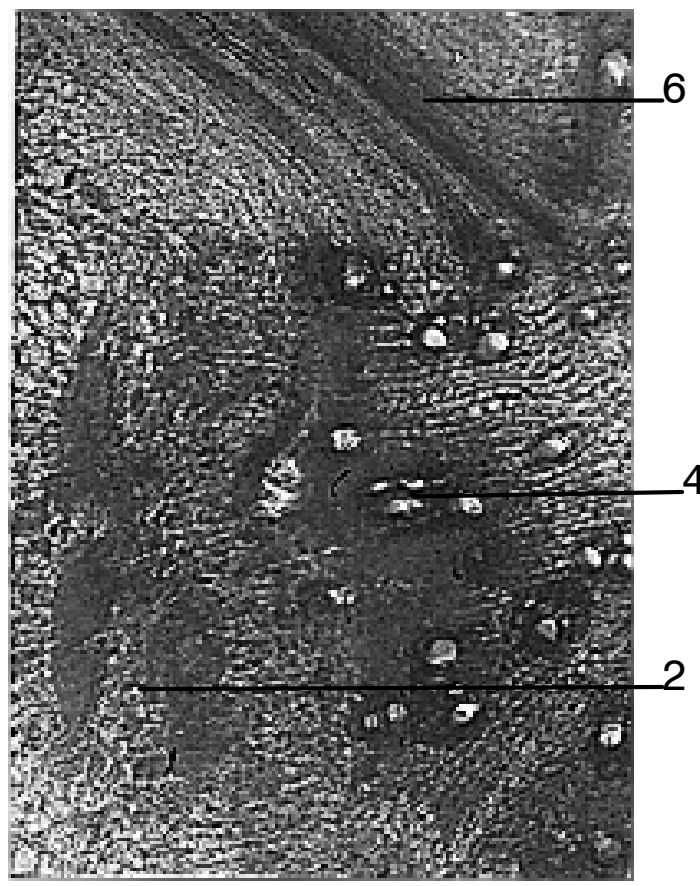

A3B1

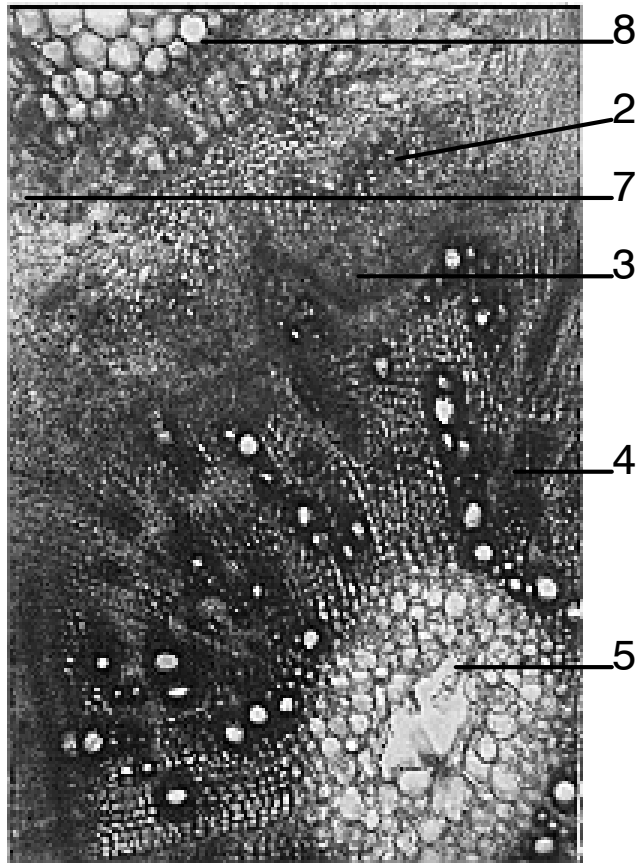

A2B2

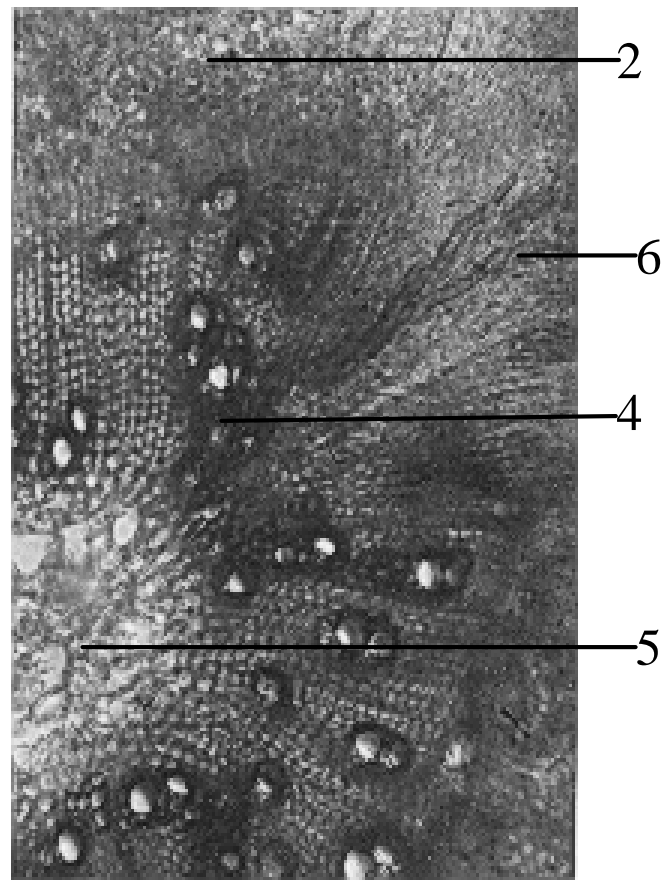

A3B2

Gambar 1. Anatomi penampang lintang akar pada berbagai perlakuan (1. korteks, 2. floem, 3. kambium, 4. xilem, 5. empulur, 6. stele akar cabang, 7. daerah terinfeksi dari bintil akar, 8.endodermis bintil akar). Perbesaran $8 \times 10$. 


\section{PEMBAHASAN}

Pemupukan dengan kompos bahan organik yang berbeda ternyata berpengaruh $(\mathrm{p}<0,05)$ terhadap panjang akar primer dan jumlah ujung akar hidup pada awal-awal pertumbuhan sebelum terbentuknya bintil akar. Setelah terbentuknya bintil akar, pemupukan juga berpengaruh $(\mathrm{p}<0,05)$ terhadap jumlah bintil pada akar primer. Kultivar yang berbeda hanya berpengaruh secara signifikan $(p<0,05)$ terhadap jumlah ujung akar hidup dan tidak pada panjang akar primer dan jumlah bintil pada akar primer. Interaksi antara pemupukan yang berbeda dan kultivar yang berbeda tidak memberikan pengaruh yang berbeda $(\mathrm{p}>0,05)$ pada semua parameter yang diamati. Bukti ini memperkuat pendapat bahwa akar tumbuhan akan memperlihatkan berbagai respons morfologis, anatomis, dan fisiologis yang berbeda ketika tumbuh menembus tanah dan perbedaan tersebut dikontrol oleh kontrol genetik, organ dan lingkungan (Fahn, 1991; Iijima dan Kono, 1992). Pada penelitian ini penyebab respons yang tampak berbeda nyata adalah faktor pemupukan.

Pertumbuhan tanaman termasuk akarnya merupakan hasil pembelahan sel-sel meristem dan pembentangan sel hasil pembelahan. Pengomposan jerami dan batang pisang dengan Agri Simba sebagai perombak memberikan nilai kandungan natrium, phosphor, dan kalium yang bervariasi pada ketiga macam kompos. Unsur-unsur hara N, P, dan K yang ada dalam kompos dapat bekerja secara sinergis untuk mempengaruhi pertumbuhan akar seperti dikemukakan oleh Irianti (1999) dan Pukan (1999).

Hasil penelitian menunjukkan bahwa akar primer terpanjang adalah pada kacang tanah yang ditumbuhkan pada media tanam plus kompos jerami. Tetapi belum cukup untuk mengatakan bahwa kegiatan pertumbuhan paling aktif pada akar yang ditumbuhkan pada media tanam plus kompos jerami. Hal ini dapat dibuktikan dengan melihat hasil pengamatan jumlah ujung akar yang hidup. Akar tersebut ternyata memiliki jumlah ujung akar yang paling sedikit dibanding yang lain.

Dari hasil pengamatan terhadap panjang dan jumlah akar, mungkin dapat diperoleh gambaran bahwa masingmasing individu mengembangkan pola perakaran yang berbeda. Pada kacang yang ditanam pada media plus kompos jerami kurang mengembangkan akar cabang. Hal ini mungkin disebabkan media tersebut paling dapat menyimpan air sehingga tersedia banyak hara yang terlarut di dalamnya. Fotosintat tidak banyak ditranslokasikan untuk pertumbuhan akar tetapi untuk pertumbuhan organ-organ di atas tanah. Karena itu perlu dilihat pertumbuhan organorgan di atas tanah. Sebaliknya kacang tanah yang ditumbuhkan pada media tanam plus kompos batang pisang paling banyak mengembangkan akar cabang. Hal ini mungkin disebabkan oleh kekurangmampuan media menyimpan air sehingga tanaman perlu menumbuhkan akar cabang untuk memperluas bidang penyerapan.

Pengomposan juga bertujuan untuk menurunkan rasio $\mathrm{C} / \mathrm{N}$. Tergantung jenis tanamannya, rasio $\mathrm{C} / \mathrm{N}$ sisa tanaman yang masih segar umumnya tinggi sehingga mendekati rasio $\mathrm{C} / \mathrm{N}$ tanah. Karena bahan jerami dan batang pisang telah dikomposkan terlebih dahulu maka $\mathrm{CO}_{2}$ dalam tanah diperkirakan tidak meningkat sehingga tidak berpengaruh buruk bagi pertumbuhan tanaman. Untuk tanah yang digunakan dalam penelitian dapat mengakibatkan daya ikatnya terhadap air menjadi besar serta struktur tanahnya menjadi tidak kasar berserat. Hal ini sesuai dengan pendapat Lingga dan Marsono (2000).

Kultivar gajah dan kelinci memberikan respons yang tidak berbeda secara signifikan ( $p>0,05)$ tetapi pemberian kompos bahan organik yang berbeda berpengaruh secara nyata $(\mathrm{p}<0,05)$ terhadap jumlah bintil. Pembentukan bintil agaknya telah terjadi jauh hari sebelum panen sehingga pada 20 hari setelah tanam telah banyak dibentuk bintil dengan penyebaran yang luas hingga hampir sepanjang akar primer. Sesuai dengan pendapat Irianti (1999) bahwa bintil akar mulai terbentuk pada 7-9 hari setelah rambut akar dan populasi Rhizobium dekat permukaan akar pada rizosfer berkembang dan akan pertumbuhan jaringannya akan berlanjut pada usia bintil sampai 18 hari. Sedangkan pada panen hari ke-8 telah tumbuh akar primer dan akar cabang, sehingga dapat diperkirakan bintil termuda terbentuk pada 15-17 hari setelah tanam.

Bintil yang teramati masih belum mencapai besar maksimum. Bintil akan mencapai besar maksimum sampai usia bintil 37 hari (Irianti, 1999). Bintil akar adalah hasil simbiosis tanaman legum dengan Rhizobium yang mampu melakukan fiksasi $\mathrm{N}_{2}$. Jumlah nitrogen yang terfiksasi dipengaruhi secara genetik oleh Rhizobium maupun inang tanaman yang spesifik (Pukan, 1999). Fiksasi nitrogen akan terus berlanjut sampai terjadi pelapukan bintil. Hasil penelitian Pukan (1999) menunjukkan bahwa jumlah bintil akar yang dibentuk oleh kacang tanah dipengaruhi oleh dosis pupuk fosfat yang diberikan. Kadar P tertinggi yang diberikan pada penelitian ini terdapat pada bokasi jerami sebesar 0,26\%. Jumlah bintil terbanyak juga dijumpai pada kacang tanah yang ditumbukan pada media tanam dengan kompos bahan jerami.

Dilihat dari jumlah bintil yang terbentuk, maka dapat dikatakan suplai nitrogen cukup untuk kebutuhan tanaman setara dengan pendapat Pasaribu dkk. dalam Pukan (1999). Distribusi bintil yang mendekati permukaan dipandang 
lebih efektif untuk fiksasi nitrogen dari udara. Dengan melihat perbedaan jumlah (dan distribusi bintil) pada akar maka perlu ditindaklanjuti pengamatan pada implikasi perbedaan tersebut terhadap produksi kacang tanah.

Pada usia 20 hari, akar telah masuk pertumbuhan sekunder. Pertumbuhan sekunder sebagai akibat kegiatan kambium juga dikendalikan oleh mekanisme pengontrolan genetik, kontrol organ, hormonal, dan lingkungan sesuai pendapat Fahn (1991), Oud dan Nanninga (1994). Pengontrolan organ dan lingkungan tanah yang berbeda karena pemberian kompos yang berbeda mungkin akan berperan dalam pembentukan struktur organ termasuk struktur akar seperti diperlihatkan oleh hasil pengamatan anatomi akar.

Awal dari invasi oleh Rhizobium mungkin melalui patahan yang secara alamiah disebabkan oleh munculnya akar lateral atau luka yang disebabkan organisme tanah. Pada irisan tampak pembintilan atau daerah terinfeksi tampak di bawah perluasan stele akar cabang/lateral. Daerah invasi terlihat berhadapan dengan salah satu atau lebih kutub tetrarch. Hal ini setara dengan pendapat Peterson (1992) yang mengamati masuknya Rhizobium pada kacang tanah.

Stimulus mekanik eksternal yang diberikan pada daerah pemanjangan dapat membawa perubahan kecepatan tumbuh dan pola pertumbuhan. Akibatnya terjadi perubahan internal jaringan (Iijima dan Kono, 1992; Oud dan Nanninga, 1994). Respons juga diperlihatkan oleh akar kacang tanah ketika menjadi tanaman inang bagi bakteri penambat nitrogen. Lapisan korteks pada daerah terinvasi menjadi tipis sedangkan pada daerah yang bersebelahan lapisan korteks tetap terlihat tebal. Setara dengan pendapat yang mengatakan bersamaan dengan invasi sel-sel tanaman inang oleh bakteri, terjadi pembelahan sel-sel korteks secara cepat/proliferasi baik sel inang yang terinvasi maupun beberapa lapis sel yang tidak terinvasi yang berdekatan. Pada daerah sebelah dalam dari bintil akar sel-sel yang terinvasi dan yang tidak terinvasi dikelilingi oleh korteks sebelah luar dari sel-sel inang yang tidak terinvasi (Pukan, 1999). Pembentukan bintil akar berimplikasi pada struktur dan perkembangan akar.

\section{DAFTAR PUSTAKA}

Bohm W, 1979. Methode of Studying Root System. SpringerVerlag, New York.

Fahn A, 1991. Anatomi Tumbuhan Ed. Ke-3. Terjemahan Sitti Soetarmi Tjitrosomo (ed), Gadjah Mada University Press, Yogyakarta.

Herlina H, Ridlo S, dan Subekti N, 2001. Pengomposan Bahan Organik dengan Agri Simba Sebagai Perombak Serta Pengaruhnya terhadap Tanaman Kacang Tanah (Arachis hypogaea L ), Hasil Penelitian, FMIPA-Universitas Negeri Semarang.

Iijima M and Kono Y, 1992. Development of Golgi Apparatus in Root Cap Cells of Maize (Zea mays L.) as Affected by Compacted Soil. Annals of Botany 70: 207-212.

Irianti Y, 1999. Pengaruh Inokulasi Rhizobium terhadap Pertumbuhan dan Pembentukan Bintil Akar Kacang Tanah (Arachis hypogaea L.) Kultivar Gajah, Skripsi: FPMIPAIKIP Semarang.

Lingga P dan Marsono, 2000. Petunjuk Penggunaan Pupuk. Penebar Swadaya, Jakarta.

Oud JL and Nanninga N, 1994. The Relation Between Cell Size, Chromosome Length and the Orientation of Chromosome in Dividing Root Cortex Cells, Plant and Soil 167: 23-29.

Peterson RI, 1992. Adaptation of Root Structure in Relation to Biotic and Abiotic Factors, Can. J. Bot. 70: 661-675.

PPAU-IH ITB, 1998. Mikroba Simba, Bandung: ITB

Pukan KK, 1999. Efektivitas Inokulan Rhizobium dan Pupuk Fosfat terhadap Pertumbuhan, Nodulasi dan Fiksasi Nitrogen pada Tanaman Kacang Tanah (Arachis hypogaea L.) Varietas Lokal Sekaran, Laporan Penelitian, FPMIPA IKIP Semarang.

Rao S, 1994. Mikroorganisme Tanah dan Pertumbuhan Tanaman, Jakarta: UI Press.

Rukmana R, 1998. Kacang Tanah, Penerbit Kanisius, Yogyakarta. Sinnott EW, 1979. Plant Morphogenesis. Robert E. Krieger Company, New York.

Suryati, 2000. Pengaruh Inokulasi Rhizobium pada Tanah Baru dan Tanah Bekas terhadap Pertumbuhan dan Produksi Tanaman Kedelai Kultivar Wilis (Glysine max L. Merill “Wilis”), Skripsi, FMIPA UNNES.

Dr. Ir. Tini Surtiningsih, DEA 